\title{
Ambulatory anesthesia: responding to the "boom" in outpatient surgery
}

\author{
Gildasio S De Oliveira Jr \\ Department of Anesthesiology, \\ Feinberg School of Medicine, \\ Northwestern University, Evanston, \\ Illinois, USA
}

This article was published in the following Dove Press journal:

Ambulatory Anesthesia

4 March 2014

Number of times this article has been viewed

The recent improvements in surgical techniques and the significant development of modern anesthetic agents have resulted in a tremendous growth in surgical procedures performed in an ambulatory setting. Currently, $70 \%$ of surgical procedures are performed in the outpatient setting. Further, the recent change in the health care system from a fee for service to pay for performance will likely result in an even greater number of surgical procedures being performed in the ambulatory setting. ${ }^{1}$

The anesthesia field has developed to accommodate the recent increase in the number of surgeries performed in the outpatient setting. ${ }^{2}$ Nevertheless, it is expected that increasing numbers of patients who undergo complex procedures and who are sicker will leave hospital on the same day of their surgical procedure. To assure the appropriate care and safety of those patients, much more research is needed in the ambulatory anesthesia field. In this context, a much-needed journal has been launched: Ambulatory Anesthesia.

The journal publishes a broad range of topics related to the care and safety of ambulatory patients. It not only focuses on traditional topics of interest to anesthesiologists, such as pharmacological interventions and anesthesia techniques, but also on regulatory issues and patient-centered outcomes. All types of article submissions (case reports, review articles and original articles) that contribute to the perioperative care of ambulatory surgical patients are therefore welcomed. A group of experts in the ambulatory anesthesia field has been assembled to compose the journal's international editorial board that will certainly be instrumental in growing the journal's reputation and readership in the coming years.

As Editor-in-Chief, my major goal for the coming year is to ensure the journal's reputation increases and, thus, make it eligible for online indexing. Although indexing is frequently the major challenge facing new journals, I do anticipate a fast process for Ambulatory Anesthesia for several reasons. First, Dove Press has a very successful history in establishing online indexing quickly, as demonstrated with its recently launched journals. Second, the ambulatory field continues to grow substantially, and there is currently no other journal fully dedicated to the scientific aspects of developing anesthetic care in these patients. I will also work to ensure that the journal review process is not only fast and fair but also that it gives authors the ability to improve their work by gaining access to experts in the field.

Correspondence: Gildasio S De Oliveira Jr Department of Anesthesiology, Feinberg School of Medicine, Northwestern University, 24I East Huron Street, F5-704 Chicago, IL 606II, USA

Email g-jr@northwestern.edu submit your manuscript | www.dovepress.com

Dovepress

http://dx.doi.org// 0.2147/AA.S59280
Ambulatory Anesthesia 2014:I I-2

(c) (i) (5) 2014 De Oliveira Jr. This work is published by Dove Medical Press Limited, and licensed under Creative Commons Attribution - Non Commercial (unported, v3.0) License. The full terms of the License are available at http://creativecommons.org/licenses/by-nc/3.0/. Non-commercial uses of the work are permitted without any further issions beyond the scope of the License are administered by Dove Medical Press Limited. Information on how to request permission may be found at: http://www.dovepress.com/permissions.php 
Please do not hesitate to contact me if you have any suggestions that may improve our journal. This coming year will certainly be a hallmark year for the ambulatory anesthesia field.

\section{Disclosure}

The author declares no conflicts of interest in this work.

\section{References}

1. Britt LD, Hoyt DB, Jasak R, Jones RS, Drapkin J. Health care reform: impact on American surgery and related implications. Ann Surg. 2013;258(4):517-526.

2. Krenk L, Jennum P, Kehlet H. Sleep disturbances after fast-track hip and knee arthroplasty. Br J Anaesth. 2012;109(5):769-775.
Ambulatory Anesthesia

\section{Publish your work in this journal}

Ambulatory Anesthesia is an international, peer reviewed, open access journal publishing articles that address all aspects of ambulatory anesthesia practice, in particular: anesthetic techniques, sedation and safety practices, pharmacokinetics, preoperative evaluation, analgesia interventions, regulatory and compliance issues, postoperative recovery,

Submit your manuscript here: http://www.dovepress.com/ambulatory-anesthesia-journal

\section{Dovepress}

patient satisfaction, administrative topics, and cost analysis themes. The manuscript management system is completely online and includes a very quick and fair peer review system, which is all easy to use. Visit http://www.dovepress.com/testimonials.php to read real quotes from published authors. 